\title{
Critical Surveillance Studies in the Information Society
}

\author{
Thomas Allmer
}

Unified Theory of Information Research Group (UTI)

Steinbrechergasse 15, 1220 Vienna, Austria

thomas.allmer@uti.at

http://www.uti.at/thomasallmer

\begin{abstract}
The overall aim of this paper is to clarify how we can theorize and systemize economic surveillance. Surveillance studies scholars like David Lyon stress that economic surveillance such as monitoring consumers or the workplace are central aspects of surveillance societies. The approach that is advanced in this work recognizes the importance of the role of the economy in contemporary surveillance societies. The paper at hand constructs theoretically founded typologies in order to systemize the existing literature of surveillance studies and to analyze examples of surveillance. Therefore, it mainIy is a theoretical approach combined with illustrative examples. This contribution contains a systematic discussion of the state of the art of surveillance and clarifies how different notions treat economic aspects of surveillance. In this work it is argued that the existing literature is insufficient for studying economic surveillance. In contrast, a typology of surveillance in the modern economy, which is based on foundations of a political economy approach, allows providing a systematic analysis of economic surveillance on the basis of current developments on the Internet. Finally, some political recommendations are drawn in order to overcome economic surveillance. This contribution can be fruitful for scholars who want to undertake a systematic analysis of surveillance in the modern economy and who want to study the field of surveillance critically.
\end{abstract}

Keywords: Surveillance Studies, Information Society, Critical Political Economy, Economic Surveillance, Workplace Surveillance, Pre-Employment Screening, Consumer Surveillance

Acknowledgement: An earlier draft of this paper was presented at the "Living in Surveillance Societies" (LiSS) annual conference at the City University London, April 14, 2010. The research presented in this paper was conducted in the project "Social Networking Sites in the Surveillance Society", funded by the Austrian Science Fund (FWF): project number P 22445G17. Project co-ordination: Prof. Christian Fuchs. I would like to thank the two anonymous reviewers for their helpful comments.

\section{Introduction}

Surveillance has notably increased in the last decades of modern society. Surveillance studies scholars like David Lyon (1994) or Clive Norris and Gary Armstrong (1999) stress that we live in a surveillance society. Although there are a lot of other features in contemporary society such as information, neoliberalism, globalization, capital, etc., surveillance is a crucial phenomenon. In order to get a first impression of surveillance, an illustrative example can be given:

According to the American Management Association and the ePolicy Institute (2008) that undertake an annual quantitative survey about electronic monitoring and surveillance with approximately 300 U.S. companies, "more than one fourth of employers have fired workers for misusing e-mail and nearly one third have fired employees for misusing the Internet". More than $40 \%$ of the companies monitor e-mail traffic of their workers, and $66 \%$ of corporations monitor Internet connections. In addition, most companies use software to block non-work related websites such as sexual or pornographic sites, game sites, social networking sites, entertainment sites, shopping sites, and sport sites. The American Management Association and the ePolicy Institute (2008) also stress that companies "tracking content, keystrokes, and time spent at the keyboard ... store and review computer files ... monitor the blogosphere to see what is being written about the company, and ... monitor social networking sites." 
The overall aim of this paper is to clarify how we can theorize and systemize such Internet phenomena. Surveillance studies scholars like Lyon (1994, 119-158; 2001, 40-44) accentuate that economic surveillance such as monitoring consumers or the workplace are central aspects of surveillance societies. The approach that is advanced in this work recognizes the importance of the role of the economy in contemporary surveillance societies. For doing so, the following thematically grouped research questions are the subject of this work:

Foundations of surveillance theory

- How is surveillance defined in the existing literature?

- What are commonalties and differences of various notions of surveillance?

- What are the advantages and disadvantages of such definitions?

Critical surveillance studies in the information society

- Which theory can be used to create a typology in order to systemize Internet surveillance in the modern economy?

- What are characteristics of Internet surveillance in the spheres of production, circulation, and consumption?

The paper at hand can be fruitful for scholars who want to undertake a systematic analysis of surveillance in the modern economy and who want to study the field of surveillance critically. Critical Surveillance Studies in the Information Society deals with surveillance in modern societies. This work is understood as a critical contribution to surveillance studies insofar as it is based on the foundations of a critical political economy approach (MECW 28; MEW 23). The concept of the modern economy means the capitalistic economy of modern societies. The modern society refers to a historical period, which has begun with the Enlightenment and lasts up to today.

This contribution constructs theoretically founded typologies in order to systemize the existing literature of surveillance studies and to analyze examples of surveillance. Therefore, it mainly is a theoretical approach combined with illustrative examples, advancing from the abstract to the concrete level. Based on the research questions and the described methodology, the following structure can be outlined:

Section two analyzes how surveillance is defined in the existing literature, what the different notions of surveillance have in common and what distinguishes them from one another, and what advantages and disadvantages such definitions have. In addition, section two elucidates how different notions treat economic aspects of surveillance and clarifies if there is a gap in the existing literature in order to study surveillance in the modern economy. The specific economic mode of surveillance is studied in section three. Based on the foundations of a political economy approach, the distinction of production, circulation, and consumption within the economy is introduced in order to establish a typology of surveillance in the economy. Furthermore, section three provides a systematic analysis of economic surveillance on the basis of current developments on the Internet. Section four concludes with a summary and makes some political recommendations in order to overcome surveillance in the modern economy.

\section{Foundations of Surveillance Studies}

Since Michel Foucault has published his book Surveiller et punir in French in 1975 and in English in 1977, the amount of literature on surveillance has increased enormously and represents a diffuse and complex field of research. Lyon (1994, 6-7) stresses: "Michel Foucault's celebrated, and contentious, historical studies of surveillance and discipline had appeared that mainstream social theorists began to take surveillance seriously in its own right". David Murakami Wood $(2003,235) \mathrm{em}-$ phasizes that "for Surveillance Studies, Foucault is a foundational thinker and his work on the de- 
velopment of the modern subject, in particular Surveillir et Punir (translated as Discipline and Punish), remains a touchstone for this nascent transdisciplinary field." According to Google Scholar, Foucault's book Discipline and Punish (1977) is almost cited 15 thousand times. According to the Encyclopedia of Philosophy (Pryor 2006, 898) and to the Routledge Encyclopedia of Philosophy (Gutting 1998, 708-713), Foucault is one of the most important historians and philosophers of the 20th century with wide influence in different disciplines.

The overall aim of this section is to elucidate how surveillance is defined in the existing literature, what the different notions of surveillance have in common and what distinguishes them from one another, and what advantages and disadvantages such definitions have. For doing so, Foucault's understanding of surveillance and the idea of the Panopticon are introduced (subsection one). Based on these findings, subsection two and three contain a systematic discussion of the state of the art of surveillance by establishing a typology of the existing literature and discussing commonalties and differences. For analyzing the existing literature on a more abstract level and identifying advantages and disadvantages, it is essential to discuss commonalties and differences and to find certain typologies. Finally, subsection four gives a summary, describes how different notions treat economic aspects of surveillance and clarifies if there is a gap in the existing literature.

\subsection{Foucault's Notion of Surveillance and the Panopticon}

Foucault $(1995 ; 2002 ; 2003 ; 2007)$ analyzes surveillance in the context of the emergence of disciplinary societies. He stresses an evolution from feudal societies of torture, to reformed societies of punishment, and on to modern disciplinary societies. In the age of torture, arbitrary penalties and public spectacles of the scaffold took place in order to exterminate bodies. Afterwards, in the age of punishment, defendants were punished and exterminated. In the age of disciplines, direct violence was replaced with softer forms of power in order to discipline, control, and normalize people in respect of drilling docile bodies and "political puppets" (Foucault 1995, 136).

For Foucault (1995, 195-210), Jeremy Bentham's Panopticon is a symbol for modern disciplinary society. "On the whole, therefore, one can speak of the formation of a disciplinary society in this movement that stretches from the enclosed disciplines, a sort of social 'quarantine', to an indefinitely generalizable mechanism of 'panopticism'“ (Foucault 1995, 216). The Panopticon is an ideal architectural figure of modern disciplinary power. It exists of an annular building divided in different cells and a huge tower with windows in the middle. Prisoners, workers, pupils, as well as patients stay in the cells and a supervisor occupies the middle tower. The architecture allows the supervisor to observe all individuals in the cells without being seen. Not every inmate is observed at every moment, but no one knows if she or he is monitored. Observation is possible anytime. As a result, everyone acts as if kept under surveillance all the time - individuals discipline themselves out of fear of surveillance. The Panopticon creates a consciousness of permanent visibility as a form of power, where no bars, chains, and heavy locks are necessary for domination any more. Foucault $(1995,228)$ finally asks: "Is it surprising that prisons resemble factories, schools, barracks, hospitals, which all resemble prisons?"

In summary, Foucault analyzes surveillance in the context of the emergence of modern disciplinary societies. He understands disciplines as forms of operational power relations and technologies of domination in order to discipline, control, and normalize people. For Foucault, the Panopticon is an ideal symbol of modern surveillance societies. Foucault's understanding of surveillance and the Panopticon allows to distinguish panoptic (affirmation of Foucault's notion) and nonpanoptic (rejection of Foucault's notion) approaches of defining surveillance that can be used for constructing a typology of existing surveillance literature and for discussing commonalties and differences of definitions of surveillance:

Non-panoptic definitions of surveillance make one or more of the following assumptions:

- Foucault's notion of the Panopticon is useless for studying surveillance nowadays. 
- Surveillance should be defined in a neutral way.

- This view uses a broad definition of surveillance.

- There are constraining and enabling effects of collecting data.

- Surveillance is primarily understood as a plural and technical process.

In comparison, panoptic definitions of surveillance make one or more of the following assumptions:

- Foucault's notion of the Panopticon is (to a certain extent) useful for studying surveillance nowadays.

- Surveillance should be defined in a negative way.

- This view uses a narrow definition of surveillance.

- Surveillance should be connected to coercion, repression, discipline, power, and domination.

- Power is primarily centralized and society tends to be repressive and controlled.

Panoptic and non-panoptic approaches of defining surveillance will be outlined. The following two subsections are therefore structured according to this distinction. The task of these subsections is to give a representative, but still eclectic overview about different definitions of surveillance.

\subsection{Non-Panoptic Theories of Surveillance}

Anthony Giddens $(1985,172-197 ; 1995,169-181)$ defines surveillance as "symbolic material that can be stored by an agency or collectivity" and as "the supervision of the activities of ordinates" (Giddens 1995, 169). He primarily sees surveillance as a phenomenon of the nation-state: "Surveillance as the mobilizing of administrative power - through the storage and control of information - is the primary means of the concentration of authoritative resources involved in the formation of the nation-state." (Giddens 1985, 181) While Foucault's negative and powerful understanding of surveillance is criticized, a neutral notion of surveillance is discussed. Surveillance is seen as documentary activities of the state, as information gathering and processing, as collection, collation and coding of information, and as records, reports and routine data collection for administrative and bureaucratic purposes of organizations. The nation-state began to keep these official statistics from its beginning and to "include the centralized collation of materials registering births, marriages and deaths; statistics pertaining to residence ethnic background and occupation; and ... 'moral statistics', relating to suicide, delinquency, divorce and so on." (Giddens 1985, 180)

Similar to Giddens, Christopher Dandeker (1990) describes surveillance as form of information gathering and administrative organization of modernity. "The term surveillance is not used in the narrow sense of 'spying' on people but, more broadly, to refer to the gathering of information about and the supervision of subject populations in organizations." (Dandeker 1990, vii)

James Rule $(1973,36 \mathrm{ff}$.) stresses in his empirical case study the idea of a total surveillance society. Although he describes the political and economic context, he uses a non-judgmental term and a broad definition of surveillance. On the one hand, obsession is crucial and required for social processes and programs and it constitutes "an ideal type of a social order" $(1973,37)$. On the other hand, collected personal data could be used in the wrong sense and has a repressive potential, too. Rule $(2007,13-17)$ still accentuates a broad term of surveillance with advantages and disadvantages in his continuing work on surveillance, published recently in his book, Privacy in Peril: Surveillance "systems share a distinctive and sociologically crucial quality: they not only collect and record details of personal information; they also are organized to provide bases for action toward the people concerned" (Rule 2007, 14). In Rule's broad understanding, surveillance as process of data collecting surveillance is not necessarily problematic and negatively connoted, because it is crucial for civic life. He combines problematic and crucial issues of data collection in one term. Although Foucault is listed in the book's bibliography, he is not mentioned once and in contrast to Foucault power relations in contemporary surveillance society are not analyzed. 
The importance of new information and communication technologies for undercover work and the differentiation between traditional and new surveillance are mentioned by Gary Marx (1988, $221 ; 2002,10 \mathrm{ff}$.). In contemporary society, surveillance has increased and so "the line between the public and the private is obliterated; we are under constant observation, everything goes on permanent record by others we do not know. Data from widely separated geographical areas, organizations, and time periods can be merged and analyzed easily" (Gary Marx 1988, 221). Surveillance is for Gary Marx primarily a technical process and defined as "the use of technical means to extract or create personal data" (Gary Marx 2002, 12). Gary Marx sees parents monitoring their baby on CCTV as example of surveillance.

In Visions of Social Control, Stanley Cohen (1987, 1-12) focuses on crime, punishment, and classification. Contemporary society has developed a whole system of classifications into good vs. bad and normal vs. abnormal, that makes control and surveillance necessary. Cohen's understanding of social control and surveillance is not quit clear: "This purpose will be served less well by any essentialist definition than simply by mapping out those 'social control matters' which this book covers. My interest is in planned and programmed responses to expected and realized deviance rather than in the general institutions of society which produce conformity. I will use the term 'social control', then, to cover matters considerably narrower and more specific" (Cohen 1987, 2f.) Nevertheless, he stresses that it is not fruitful if social control is used as negative term and if powerful abstractions of ideological and repressive state apparatus are analyzed as Marxists did. In modern society power and domination are not centralized, but rather everyone can get a powerful position.

For James Beniger (1986), control and surveillance are general concepts of "purposive influence toward a predetermined goal" (Beniger 1986, 7), where the "information storage, processing, and communication" (Beniger 1986, 62) are stressed.

Computer scientist Roger Clarke (1988, 498-499; 505f.) defines surveillance as "the systematic investigation or monitoring of the actions or communications of one or more persons. Its primary purpose is generally to collect information about them, their activities, or their associates. There may be a secondary intention to deter a whole population from undertaking some kinds of activity." (Clarke 1988, 499) For Clarke, surveillance and dataveillance are neither negative nor positive as it depends on the situation. "I explicitly reject the notion that surveillance is, of itself, evil or undesirable; its nature must be understood, and society must decide the circumstances in which it should be used". (Clarke, 1988, 498f.) Although many dangers and disadvantages of surveillance in general and dataveillance in particular are mentioned, benefits like physical security of people and financial opportunities in both public (social welfare and tax) and private (insurance and finance) sector are listed as well.

David Lyon (1994, viii-x) grasps surveillance "as a shorthand term to cover the many, and expanding, range of contexts within which personal data is collected by employment, commercial and administrative agencies, as well as in policing and security" (Lyon 1994, ix). He suggests a neutral understanding of surveillance with positive and negative effects of constraining and enabling. Surveillance is undemocratic, coercive, impersonal or even inhuman on the one hand, but it is as well "innocuous or a channel of positive blessing" (Lyon 1994, ix) on the other hand. Lyon (2001, 3) emphasizes watching over a child and taking care of it as positive aspects of surveillance. In addition, he understands CCTV as an instrument that us used for keeping modern society secure and safe, because "the camera is installed in the bar or at the intersection in order to reduce rowdiness or road accidents. No one wants trouble when relaxing at the bar and no one wants to end up in hospital because someone ran a red light." (Lyon 2001, 39)

In Forget Foucault, Jean Baudrillard $(2007,34)$ dismisses Foucault's concept of the Panopticon: "The same goes for Discipline and Punish, with its theory of discipline, of the 'panoptic' and of 'transparence.' A magistral but obsolete theory. Such a theory of control by means of a gaze that objectifies, even when it is pulverized into micro-devices, is passe. With the simulation device we are no doubt as far from the strategy of transparence as the latter is from the immediate, symbolic operation of punishment which Foucault himself describes. Once again a spiral is missing here, the spiral in front of which Foucault, oddly enough, comes to a halt right at the threshold of a current 
revolution of the system which he has never wanted to cross". Baudrillard $(2006,28-32)$ stresses the end of the panoptic system and analyzes surveillance in the era of simulation and simulacra. In this context, he blurs the distinction between active and passive forms of surveillance. A mutation of the real into the hyperreal takes place and the essence of power disappears. "Something else in regard to the Louds. 'You no longer watch TV, it is TV that watches you (live),' or again: 'You are no longer listening to Don't Panic, it is Don't Panic that is listening to you' - a switch from the panoptic mechanism of surveillance (Discipline and Punish [Surveiller et punir]) to a system of deterrence, in which the distinction between the passive and the active is abolished. There is no longer any imperative of submission to the model, or to the gaze 'YOU are the model!' 'YOU are the majority!' Such is the watershed of a hyperreal sociality, in which the real is confused with the model, as in the statistical operation, or with the medium, as in the Louds' operation. Such is the last stage of the social relation, ours, which is no longer one of persuasion (the classical age of propaganda, of ideology, of publicity, etc.) but one of deterrence: 'YOU are information, you are the social, you are the event, you are involved, you have the word, etc.' An about-face through which it becomes impossible to locate one instance of the model, of power, of the gaze, of the medium itself, because you are always already on the other side. No more subject, no more focal point, no more center or periphery: pure flexion or circular inflexion. No more violence or surveillance: only 'information', secret virulence, chain reaction, slow implosion, and simulacra of spaces in which the effect of the real again comes into play." (Baudrillard 2006, 29f.)

Based on Baudrillard, William Bogard $(1996,1 \mathrm{ff}$.) focuses on the simulation of hypersurveillant control in telematic societies. He defines bureaucratic surveillance as "information gathering and storage systems (accounting, recording, and filing mechanisms) and the various devices for encoding and decoding that information (impersonal, standardized rules governing its access, use, and dissemination)." (Bogard 1996, 1f.) He argues that surveillance ranges between absolute control in disciplined societies and the absence of control in non-disciplined societies. Bogard (2006, 97-101) understands surveillance as decentralized networks, where monopolized power and control of information become more impossible. Surveillance is both a mode of oppressed capture and a mode of lines flight of "escape, deterritorialization, indetermination and resistance" (Bogard 2006, 101).

In The Maximum Surveillance Society, Clive Norris and Gary Armstrong (1999, 3-12) consider surveillance as an ambivalent process with protective and enabling elements and totalitarian and powerful effects. Although the power of surveillance is mentioned, they do not want to automatically apply the idea of a powerful Panopticon or of a totalitarian Big Brother state to the rise of CCTV ( also Norris and Armstrong 1998, 7). The deployment of CCTV is not equal to one single Big Brother and it does not enable some singular disciplinary norms. "We need to be cautious about merely equating the power to watch with the disciplinary power implied in Foucault's concept of panoptic surveillance. Similarly, the spread of cameras should not automatically be assumed to herald the arrival of a totalitarian 'Big Brother' state." (Norris and Armstrong 1999, 6) Accordingly, it is seen more useful to refer to the works of James Rule, whose ideas influence the book to a certain extent.

People's active role in the context of surveillance is emphasized by Hille Koskela $(2004,199$; $2006,175)$. For instance, reality shows are based on viewer participation, mobile phones with cameras create an active subject, and home webcams generate new subjectivities. She wants to analyze "the other side of surveillance", which has resistant and liberating elements. "Webcams can also be argued to contribute to the 'democratization' of surveillance." (Koskela 2006, 175) Kosekela argues that webcams have an empowering role and that the active role of individuals with surveillance equipment shows that the lines of control are blurred.

Roy Boyne $(2000,285)$ uses the term post-Panopticism and argues against the basic panoptical paradigm: "The theoretical arguments in favour of abandoning the concept of the Panopticon (from Bauman, Bogard, Latour and others) are considered under five headings: displacement of the Panoptical ideal by mechanisms of seduction; redundancy of the Panoptical impulse brought about by the evident durability of the self-surveillance functions which partly constitute the normal, socialized, 'Western' subject; reduction in the number of occasions of any conceivable need for Panopti- 
cal surveillance on account of simulation, prediction and action before the fact; supplementation of the Panopticon by the Synopticon; failure of Panoptical control to produce reliably docile subjects." (Boyne 2000, 285)

Based on Deleuze's and Guattari's ideas, Kevin Haggerty and Richard Ericson (2000, 605-620) combine surveillance with assemblages and come to develop the concept of surveillant assemblage. An assemblage is an entity that consists of different flowing objects or multiple phenomena and processes that work together. An assemblage contains multiple discrete assemblages and it is at the same time part of a greater assemblage. "Lines and measurable speeds, constitutes an assemblage. ... As an assemblage, a book has only itself, in connection with other assemblages and in relation to other bodies without organs. ... An assemblage is precisely this increase in the dimensions of a multiplicity that necessarily changes in nature as it expands its connections. ... An assemblage establishes connections between certain multiplicities drawn from each of these orders, so that a book has no sequel nor the world as its object nor one or several authors as its subject." (Deleuze and Guattari 1987, 4; 8; 23) Haggerty and Ericson stress that surveillance has the potential to put different systems, practices, and technologies together into a larger whole and talk of surveillance as an assemblage. Additionally, rhizomatic surveillance as an interconnected system is analyzed. A rhizome is an interconnected root and represents a decentral network. Deleuze and Guattari list characteristics of a rhizome: "Principles of connection and heterogeneity" $(1987,7)$, "principle of multiplicity" $(1987,8)$, "principle of a signifying rupture" $(1987,9)$, and "principle of cartography and decalcomania" $(1987,12)$. As surveillance is organized like a networked rhizom, an enormous expansion took place in the last decades. According to Haggerty and Ericson, surveillance is understood as a decentralized, non-hierarchical phenomenon without a certain powerful group or institution. While Haggerty and Ericson $(2000,607)$ are neither interested in analyzing Foucault's concept of surveillance because it "fails to directly engage contemporary developments in surveillance technology" $(2000,607)$ nor in incorporating new approaches that are based on Foucault because they are "providing little that is theoretically novel" $(2000,607)$, they introduce the term synopticism in contrast with Panopticism. The emergence of new media and inexpensive video cameras allows the general public to keep someone synoptically under surveillance. "Synopticism signifies that many individuals are able to observe and control a certain phenomenon or process. Synopticism essentially means that a large number of individuals are able to focus on something in common." (Haggerty and Ericson 2000, 618) Haggerty and Ericson (2000,617) mention the media circus surrounding Britain's royal family as an example and conclude: "Surveillance has become rhizomatic, it has transformed hierarchies of observation, and allows for the scrutiny of the powerful by both institutions and the general population."

Roy Coleman and Joe Sim $(2000,623 ; 635)$ publicized an empirical case study about CCTV surveillance in Liverpool. They stress a shift of power from Foucault's concept towards multiple centres of government, localized mechanisms of rule, and autonomous forms of knowledge. Surveillance and social control are understood as networked phenomena and partnerships acting at a distance. "Within this discourse CCTV cameras can be understood as helping to create public spaces for 'free', 'responsible', consumer-oriented individuals who independently choose their autonomous role in the life of the city. Thus CCTV is constructed around the idea of 'empowerment' and 'freedom', particularly the 'freedom and safety to shop'." (Coleman and Sim 2000, 635)

Katherine Williams and Craig Johnstone (2000, 183-193) make a re-reading of video surveillance and criticize the idea to see CCTV in the context of the Panopticon. The panoptical notion stresses an all-encompassing visibility and control, but CCTV is only available at selected streets and places. The authors emphasize the concept of a selective gaze because the Panopticon in their view leads to a misleading interpretation of CCTV: "By emphasising the selective gaze rather than the all-encompassing Panopticon, we are attempting to open the analysis up to a more complex, and perhaps more nuanced, encounter with a range of different issues associated with surveillance, policing and the use of public space." (Williams and Johnstone 2000,192)

Sean Hier $(2004,542-546)$ explores emotional repertoires and cultural milieus of public video surveillance program and undertakes a selective reading of Foucault's notion of the Panopticon. 
Hier criticizes approaches that understand surveillance predominantly as a mechanism of repression, because "the routine disciplinary mechanics of surveillance need not fundamentally be located with elite partnerships or some abstracted governmental body" (Hier 2004, 546). Although Hier $(2003,403)$ rejects the idea of the non-hierarchical rhizomatic surveillant assemblage, he suggests understanding surveillance as a multifaceted structure of consent and coercion with inclusionary and exclusionary impulses that does not automatically involve punishment. ( Hier 2004, 546).

Although Elia Zureik (2003, 42; 46-49) emphasizes the importance of the political economy of surveillance and theorizes surveillance in the case of the workplace, he gives a rather neutral understanding of surveillance with enabling and disabling functions: "Surveillance is (1) an ubiquitous feature of human societies, and is found in both the political (public) and civil (private) sphere of society; (2) associated with governance and management; (3) endemic to large-scale organizations; (4) constitutive of the subject and has a corporeal aspect to it; (5) disabling as well as enabling and is "productive" in Foucault's sense; (6) understood in terms of distanciation, i.e., the control of space and time; (7) becoming increasingly implicated in a system of assemblage which brings together diverse control technologies; and (8) rhizomatic, as evident in the ability of convergent technologies to capture and assemble inordinate amounts of information about people from various sources." (Zureik 2003, 42)

Michalis Lianos $(2003,412-427)$ wants to analyze social control after Foucault and rejects the latter's contribution, because "the Foucauldian model of control, and consequently its explanatory power, refers to the past and is not concerned with the emergence of the contemporary postindustrial subject." (Lianos 2003, 413) As a result, "we must stop projecting his [Foucault's; TA] analyses onto objects of study that they were not made for, and take the risk of approaching these objects of study with the subtlety and originality that they demand." (Lianos 2003, 427) Instead, Lianos pleads for a new theoretical paradigm considering control in the interaction between users and institutions, the emergence of neutral and unintended control, and the contribution of sociotechnical systems.

For Anders Albrechtslund (2008), positive aspects of being under surveillance are worth mentioning and he argues that surveillance also empowers the users, constructs subjectivity, and is playful. Surveillance as social and participatory act involves mutuality and sharing. "Surveillance in this context offers opportunities to take action, seek information and communicate." (Albrechtslund 2008) Although Albrechtslund and Dubbeld $(2005,216)$ do not want to ignore the controlling aspects of surveillance, they study its entertainment values and fun features. Surveillance is a play and art and "could be considered not just as positively protective, but even as a comical, playful, amusing, enjoyable practice" (Albrechtslund and Dubbeld 2005, 216).

In summary, many scholars use a neutral and general notion and stress non-panoptic elements of surveillance, where everyone has the opportunity to surveil. This approach applies a broad definition of surveillance and stresses constraining and enabling effects of collecting data. Surveillance is primarily understood as a plural, neutral, and technical process. Nevertheless, there are theorists who analyze surveillance based on Foucault in the context of the Panopticon and stress powerful and disciplinary elements of contemporary surveillance societies.

\subsection{Panoptic Theories of Surveillance}

Gilles Deleuze (1992, 3-7; also 1988, 23-46) underlines a mutation of capitalism in Postscript on the Societies of Control. Based on the ideas of Foucault, he describes the change from the disciplinary societies to the societies of control. He speaks of a change in the mode of institutions, production, culture, and technique that creates a new level of control in social subsystems. "The operation of markets is now the instrument of social control" (Deleuze 1992, 6). The school system has been commercialized and is dominated by corporations, which presents a new form of control. The economic system has developed new forms of production and marketing. The hospital system substitutes for the body a controlling code to be controlled and the prison system developed the use of electronic collars for more efficient controllability. For Deleuze $(1992,7)$ technical changes in the societies of control are crucial and he mentions that "what counts is not the barrier but the computer that tracks each person's position--licit or illicit--and effects a universal modulation". Further- 
more, society has become data, markets, and samples. Deleuze describes the neoliberal area of capitalism and emphasizes the emergence of control and surveillance as necessary part in it. The control societies are for him not just societies of data collecting, but rather societies full of power, struggles, domination, and control. "These are very small examples, but ones that will allow for better understanding of what is meant by the crisis of the institutions, which is to say, the progressive and dispersed installation of a new system of domination." (Deleuze 1992, 7)

Also interesting in this context is the dystopian novel Nineteen Eighty-Four by George Orwell (2004), first published in 1949. Orwell describes a ruling system called Oceania, which consists of Big Brother, the party and the proles and stands for pervasive government surveillance, totalitarian regime and public mind control. "Every citizen, or at least every citizen important enough to be worth watching, could be kept for twenty-four hours a day under the eyes of the police and in the sound of official propaganda, with all other channels of communication closed. The possibility of enforcing not only complete obedience to the will of the State, but complete uniformity of opinion on all subjects, now existed for the first time." (Orwell 2004, 255)

Shoshana Zuboff $(1988,315 \mathrm{ff}$.) studied the emergence of information technologies at the workplace in her book In the Age of the Smart Machine, where she defines authority as "the spiritual dimension of power" (Zuboff 1988, 219) and technique as "the material dimension of power" (Zuboff 1988, 311). Based on Foucault's disciplinary societies, she stresses the panoptic power of information technology in corporate institutions and presents empirical case studies. Furthermore, new technologies at the workplace have brought a universal transparency, increased hierarchy and control, and they provide the management with a full bird's-eye view to counter the behaviour of their workers.

In Foucault's tradition, Mark Poster (1990, 69-98) understands surveillance as "a major form of power in the mode of information" (Poster 1990, 86). Poster emphasizes that technological change has caused new forms of surveillance and an electronic Superpanopticon in the postmodern and postindustrial mode of information. A Superpanopticon is a process of normalizing and controlling masses and a form of computational power. "Today's 'circuits of communication' and the databases they generate constitute a Superpanopticon, a system of surveillance without walls, windows towers or guards. The quantitative advances in technologies of surveillance result in a qualitative change in the microphysics of power. ... The Superpanopticon imposes a new language situation that has unique, disturbing features" (Poster 1990, 93f.) Poster stresses that new information and communication technologies have advanced new forms of surveillance and therefore new forms of power.

For Oscar Gandy (1993, 1-13), panoptic surveillance is a "complex technology that involves the collection, processing, and sharing of information about individuals and groups that is generated through their daily lives as citizens, employees, and consumers and is used to coordinate and control their access to the goods and services that define life in the modern capitalist economy" (Gandy 1993, 15). Gandy notices surveillance as a complex high-tech system of power, where people are sorted into categories in order to identify, classify, and assess them. Furthermore, surveillance is used to normalize and homogenize behaviour with discriminatory elements in a structure of hierarchical observation.

Frank Webster and Kevin Robins (1993, 244-246) analyze surveillance in the context of Taylorism. Frederick Winslow Taylor's development of Scientific Management "provides management with a codification of purpose" (Webster and Robins 1993, 245) in order to accumulate knowledge and information in the production process. For realizing Taylor's scientific management, a system of information gathering and surveillance is necessary. "The panopticon is the precursor of Scientific Management." (Webster and Robins 1993, 245) Webster and Robins point out the development of modern surveillance societies: "A line of descent is traceable from Bentham's original conception of the panopticon, through Taylor's development of Scientific Management, to the current notion of neo-Fordism or flexible accumulation ... What is common throughout is the central concern with information/surveillance." (Webster and Robins 1993, 245) Just-in-Time and Total Quality Control as new forms of post-Fordist production process "appear to bring decentralization while in 
fact increasingly centralising power" (Webster and Robins 1993, 243) Additionally, Robins and Webster $(1999,90)$ refer to Foucault's ideas of the Panopticon and describe surveillance in the context of control, repression, discipline, and power: "To echo Foucault's words, it is not possible for social planning and administration to be exercised without surveillance, it is impossible for surveillance not to reinforce administrative cohesion, efficiency, and power." (Robins and Webster $1999,90)$ Primarily political and economic forms of surveillance are analyzed and it is argued that corporations use monitoring of markets for propaganda and to control consumer groups.

John Fiske (1999, 125ff.; 217ff.) focuses on surveillance as possibility to collect certain knowledge about other people. He gives examples of counter-hegemonic surveillance and refers to the Rodney King video (a privately video-taped happening, which shows an African American man, who was the victim of police brutality). Fiske argues that especially the easy access to home video cameras has made it possible to surveil the surveillers and to enable "those who are normally the object of surveillance to turn the lens of reverse its power" (Fiske 1999, 127). Nevertheless, he argues that there are social groups, which have preferred abilities to watch others; hence, there is an unequal access and power to surveil in contemporary society. In Foucault's tradition, surveillance is stressed as oppressive and totalitarian method of power. "I believe that surveillance is rapidly becoming the most efficient form of power, the most totalitarian and the hardest to resist." (Fiske 1999, 218) Furthermore, Fiske $(1998,67 \mathrm{ff}$.) analyzes surveillance in the context of racism. Surveillance cameras are used as control mechanism especially against black people in public space. Fiske emphasizes that surveillance operates differently upon black and white people and works in a powerful and racialized context. "Surveillance is a technology of whiteness that racially zones city space by drawing lines that Blacks cannot cross and whites cannot see. Surveillance enables different races to be policed differently." (Fiske 1998, 69)

Thomas Mathiesen (1997) revisits Foucault's Panopticon in The viewer society and argues that in modern society not only the few see the many as Foucault has articulated, but also the many see the few and introduces in contrast to the Panopticon the term Synopticon - a combination of the Greek word "syn" = together, at the same time and "opticon" = visual (Mathiesen 1997, 219). The scholar stresses that modern mass media especially television make possible to see the few and that both Panopticon as well as Synopticon are important elements of modern society, which create the viewer society. Mathiesen accentuates three parallels of panoptical and synoptical developments, namely "the acceleration which synopticism as well as panopticism has shown in modern times, that is, during the period 1800-2000" (Mathiesen 1997, 219), that "they are archaic, or 'ancient', as means of potential means of power in society" (Mathiesen 1997, 222) and that they "have developed in intimate interactions, even fusion, with each other" (Mathiesen 1997, 223). Most important in the Synopticon, news reporters, media personalities, and commentators "actively filter and shape information; as has been widely documented in media research, they produce news ...; they place topics on the agenda and avoid placing topics on the agenda ... Those who are allowed to enter [the media from the outside; TA] are systematically men - not women - from the higher social strata, with power in political life, private industry and public bureaucracy ... The information professionals have become highly visible and valuable sources of information for the media; informational activity has become an occupation. The information professionals are trained to filter information, and to present images which are favourable to the institution or organization in question." (Mathiesen 1997, 226f.) Therefore, not only the Panopticon but also the Synopticon makes individuals silent and directs, controls, and disciplines our consciousness (Mathiesen 1997, 230). As a result, the author concludes: "Taken as a whole, things are much worse than Michel Foucault imagined." (Mathiesen 1997, 231).

Greg Elmer (2003, 231-245; see also 2004) draws upon the work of Foucault, Varela, Deleuze, and Guattari and outlines a diagram of panoptic surveillance: "With the help of Foucault and his 'interlocutors' Gilles Deleuze and collaborator Felix Guattari, this article conversely theorizes panoptic surveillance as a multiplicity of processes that work to increasingly quantify and qualify not only the specific behaviours of consumers (or other sales, inventory or distribution data), but also the efficiency of the panoptic process itself. It is argued that one cannot provide such an overarch- 
ing theory of surveillance - or even appreciate the specific dynamics of panopticism (such as data accumulation or storage) - by privileging any one step in the process of panoptic surveillance. That is, by focusing exclusively on questions such as: how is personal information solicited? Or, how and where is personal information and other forms of consumer data stored (in databases or networked systems)? Consequently, in explicating the diagrammatic characteristics of panoptic surveillance, this article attempts to account for the way in which consumers and their data-selves become continuously integrated into the act of collecting, storing, and cross referencing a multitude of consumer market data (i.e. inventory - distribution - sales)." (Elmer 2003, 233)

In regard to Foucault's Panopticon, Didier Bigo (2006, 46ff.; 2008, 10-38) highlights ban-opticon dispositif in globalized spaces. The United States has propagated a global insecurity of crime and terrorism and has created a governmentality of unease, where global police networks are necessary. These ideas permit transnational regimes to close borders, to declare certain exceptions, to signify differences, to create an image of terrorists, and to profile and contain foreigners. "It allows us to analyse the collection of heterogeneous bodies of discourses (on threats, immigration, enemy within, immigrant fifth column, radical Muslims versus good Muslims, exclusion versus integration, etc.), of institutions (public agencies, governments, international organizations, NGOs, etc.), of architectural structures (detention centres, waiting zones and Schengen traffic lanes in airports, integrated video camera networks in some cities, electronic networks outfitted with security and video-surveillance capacities), of laws (on terrorism, organized crime, immigration, clandestine labour, asylum seekers, or to accelerate justice procedures and to restrict the defendants' rights), and of administrative measures (regulation of the 'sans papiers', negotiated agreements between government agencies vis-à-vis policies of deportation/repatriation, 'common' aeroplanes specially hired for deportation with costs shared by different national polices, etc.)." (Bigo 2008, 32) While certain groups are excluded and under surveillance, the non-excluded majority is normalized and disciplined. Hence, there is a fragmented and heterogeneous contradiction of inclusion and exclusion in surveilled global spaces.

Graham Sewell and Barry Wilkinson $(1992,271)$ scrutinize surveillance in the labour process and draw parallels between Foucault's ideas of power, knowledge and surveillance and the phenomenon of post-Fordism. According to these authors, Just-in-Time (JIT) and Total Quality Control (TQC) regimes are improved surveillance techniques that aim at the optimization of disciplinary power and the control of the labour process. JIT and TQC are methods, which provide an organizational structure and over-arching controlling mechanism and elaborate the post-Fordist production process: "We demonstrate that the surveillance systems integral to JIT/TQM are deliberately designed such that discipline is established in a most efficient manner and the exercise of minute control is possible with a minimum of supervisors. The desired effect of harnessing these dual forces is to minimise negative divergences from expected behaviour and management defined norms whilst identifying positive divergencies and maximising their creative potential." (Sewell and Wilkinson 1992, 271)

Jean-François Blanchette and Deborah Johnson (2002, 33-35; 43) examine data retention as well as the rise of panoptic society and stress the disappearance of social forgetfulness. Surveillance and data retention have made social forgetfulness irrelevant. Data retention hinders the opportunity for a second chance and for a new and upstanding life, because it allows storing data about individual crimes from the past. Blanchette and Johnson $(2002,33)$ examine "three domains in which social policy has explicitly recognized the importance of such a principle: bankruptcy law, juvenile crime records, and credit reports". For Blanchette and Johnson, the disappearance of social forgetfulness makes surveillance even more powerful and indicates that a panoptic society is being put into place: "Unless data retention issues are addressed explicitly as part of a comprehensive policy approach to personal privacy, we will gradually move to a panoptic society in which there is little social forgetfulness and little, if any, opportunity to move on beyond one's past and start afresh." (Blanchette and Johnson 2002, 43) It is argued that data have predictive power.

Asymmetrical characteristics and unbalanced power relationships of panoptic surveillance are also emphasized by Steve Mann, Jason Nolan, and Barry Wellman (2003, 332-336). Based on 
Foucault's panoptic notion, Mann, Nolan, and Wellman claim the rise of neo-Panopticons with new communication technologies. Subjects of neo-Panopticons do not have direct contact with the observers and "are under the potential control of people in positions of authority who are organizational monitors of their behavior. They are like the subjects of a king, a dictator, authority figure, or organizational institution." (Mann, Nolan, and Wellman 2003, 335). Additionally, they introduce the term sousveillence, which was first developed by Mann. Sousveillence is a form of inverse surveillance using tools and technologies in order to observe the organizational observer and to surveil the surveiller: "One way to challenge and problematize both surveillance and acquiescence to it is to resituate these technologies of control on individuals, offering panoptic technologies to help them observe those in authority. We call this inverse panopticon 'sousveillance' from the French words for 'sous' (below) and 'veiller' to watch." (Mann, Nolan, and Wellman 2003, 332)

A different reading of Foucault is undertaken by Paulo Vaz and Fernanda Bruno (2003, 272277). They want to open the concept in order to focus on subjectivity, care of the self, and practices of self-surveillance. Self-surveillance is based on (productive) power and normalizing judgement and it is analyzed in the context of disciplinary society. Because individuals are not able to realize if they are actually being observed or not, they discipline themselves, internalize power, and constitute as a normal citizen. If experiences of self-surveillance "are to be seen as an extension and intensification of the panopticon principles, we would be running the risk of living in a totalitarian age today." (Vaz and Bruno 2003, 276)

Stuart Elden $(2003,24 \mathrm{ff}$.) undertakes a precise study of Foucault's notion of surveillance and analyzes only partly translated lectures and seminars from this period. He criticizes traditional Foucauldian approaches of surveillance, because they tend to overemphasize the figure of Panopticon at the expense of other writings of Foucault; hence, they are eclectic. Although analyzing the Panopticon is important and crucial, it only covers a few pages and power cannot be reduced to this figure. Elden argues that control mechanisms and surveillance have more in common with the plague towns and the leper and suggests that "the analysis of medicine may be a more profitable model for surveillance than the Panopticon" (Elden 2003, 240).

Bart Simon $(2005,1-5)$ highlights a return of the Panopticism and analyzes surveillance in the context of power, subjection, normalization, internalization, and social control. Simon finds it fruitful studying surveillance based on Foucault, because his "model both allows for these twin concerns within the context of the new surveillance while serving as a source of further insight into the empirical nuances of contemporary surveillance relations." (Simon 2005, 1)

Summing up, these approaches consider surveillance to be always negative and being connected to coercion, repression, discipline, power, and domination. For these authors, power is primarily centralized and society tends to be repressive and controlled. This view emphasizes panoptical elements and uses a narrow definition of surveillance.

\subsection{Discussion}

The overall aim of this section was to clarify how surveillance is defined in the existing literature and what the different theories of surveillance have in common and what distinguishes them from one another. For doing so, Foucault's understanding of surveillance and the idea of the Panopticon were introduced. Based on these findings, a systematic discussion of the state of the art of surveillance by establishing a typology of the existing literature and a discussion of commonalties and differences were introduced. The following table summarizes the results. 


\begin{tabular}{|c|c|c|}
\hline \multicolumn{3}{|c|}{ Foundations of Surveillance Theory } \\
\hline $\begin{array}{l}\text { Non-Panoptic } \\
\text { Theories of } \\
\text { Surveillance }\end{array}$ & $\begin{array}{l}\text { Many scholars use a neutral and } \\
\text { general notion and stress non- } \\
\text { panoptic elements of surveillance. } \\
\text { This approach applies a broad defini- } \\
\text { tion of surveillance and stresses con- } \\
\text { straining and enabling effects of col- } \\
\text { lecting data. Surveillance is primarily } \\
\text { understood as a plural, neutral, and } \\
\text { technical process. }\end{array}$ & $\begin{array}{l}\text { Anthony Giddens (1985; 1995), } \\
\text { Christopher Dandeker (1990), } \\
\text { James Rule (1973; 2007), Gary } \\
\text { Marx (1988; 2002), Stanley } \\
\text { Cohen (1987), James Beniger } \\
\text { (1986), Roger Clarke (1988), } \\
\text { David Lyon (1994; 2001), Jean } \\
\text { Baudrillard (2006; 2007), Wil- } \\
\text { liam Bogard (1996; 2006), Clive } \\
\text { Norris and Gary Armstrong } \\
\text { (1998; 1999), Hille Koskela } \\
\text { (2004; 2006), Roy Boyne } \\
\text { (2000), Kevin Haggerty and } \\
\text { Richard Ericson (2000), Roy } \\
\text { Coleman and Joe Sim (2000), } \\
\text { Katherine Williams and Craig } \\
\text { Johnstone (2000), Sean Hier } \\
\text { (2003; 2004), Elia Zureik } \\
\text { (2003), Michalis Lianos (2003), } \\
\text { Anders Albrechtslund (2008) }\end{array}$ \\
\hline $\begin{array}{l}\text { Panoptic } \\
\text { Theories of } \\
\text { Surveillance }\end{array}$ & $\begin{array}{l}\text { This approach considers surveillance } \\
\text { to be always negative and being } \\
\text { connected to coercion, repression, } \\
\text { discipline, power, and domination. } \\
\text { For these authors, power is primarily } \\
\text { centralized and society tends to be } \\
\text { repressive and controlled. This view } \\
\text { emphasizes panoptical elements and } \\
\text { uses a narrow definition of surveil- } \\
\text { lance. }\end{array}$ & $\begin{array}{l}\text { Gilles Deleuze (1988; 1992), } \\
\text { George Orwell (2004), Shosha- } \\
\text { na Zuboff (1988), Mark Poster } \\
\text { (1990), Oscar Gandy (1993), } \\
\text { Frank Webster and Kevin Rob- } \\
\text { ins (1993; 1999), John Fiske } \\
\text { (1998; 1999), Thomas } \\
\text { Mathiesen (1997), Greg Elmer } \\
\text { (2003; 2004), Didier Bigo (2006; } \\
\text { 2008), Graham Sewell and } \\
\text { Barry Wilkinson (1992), Jean- } \\
\text { François Blanchette and Debo- } \\
\text { rah Johnson (2002), Steve } \\
\text { Mann, Jason Nolan, and Barry } \\
\text { Wellman (2003), Paulo Vaz and } \\
\text { Fernanda Bruno (2003), Stuart } \\
\text { Elden (2003), Bart Simon } \\
\text { (2005) }\end{array}$ \\
\hline
\end{tabular}

Table 1: Foundations of surveillance theory

In conclusion, non-panoptic theories use a neutral and general notion of surveillance, where everyone has the opportunity to surveil; they are represented by scholars such Anthony Giddens, James Rule, Gary Marx, and Jean Baudrillard. In contrast, panoptic theories consider surveillance to be negative and being connected to coercion, repression, discipline, power, and domination; they are represented by scholars such as Gilles Deleuze, Oscar Gandy, Frank Webster and Kevin Robins, and Mark Poster.

Although private actors monitor and watch over other individuals in everyday life experiences (for example parents taking care of their children, providing personal information on Weblogs, and 
using social networking sites on the Internet), these acts are processes to which people agree and which involve no violence, coercion, or repression. In comparison, economical and political actors use surveillance and exercise violence in order to control a certain behaviour of people and in most cases people do not know that they are surveilled. Corporations control the economic behaviour of people and coerce individuals in order to produce or buy specific commodities for accumulating profit and for guaranteeing the production of surplus value. Corporations and state institutions are the most powerful actors in society and are able to undertake mass-surveillance extensively and intensively (such as for example the collection and gathering of information on Internet user profiles in order to implement targeted advertising), because available resources decide surveillance dimensions. In the modern production process, primarily electronic surveillance is used to document and control workers' behaviour and communication for guaranteeing the production of surplus value. The commodification of privacy is important to target advertising for accumulating profit. State institutions have intensified and extended state surveillance of citizens in order to combat the threat of terrorism (see Gandy, 2003; Lyon 2003) Therefore, one can assume that corporations and state institutions are the main actors in modern surveillance societies and surveillance is a crucial element for modern societies.

Non-panoptical notions use a broad definition of surveillance and tend to mix up very heterogeneous phenomena on one level of analysis: If for example pretty harmless experiences like watching a baby on the one hand and for powerful economic and political surveillance on the other hand the same term is used, it becomes difficult to criticize contemporary surveillance phenomena such as for example CCTV, Internet surveillance, the EU data retention directive, biometrical iris scanners, facial recognition software, Computer Assisted Passenger Prescreening System (CAPPS), and the collection of DNA samples (Fuchs 2008, 273ff.). Furthermore, non-panoptic notions understand surveillance in a non-hierarchical and decentralized way, where everyone has the opportunity to surveil. This argument overlooks the fact that corporations and state institutions are the most powerful actors in society and are able to undertake mass-surveillance, what private actors are not able to do. Neutral concepts of surveillance tend to overlook the power asymmetries of contemporary society and therefore tend to convey the image that private actors are equally powerful as corporations and state institutions. Hence, a general and neutral understanding of surveillance is not fruitful for studying surveillance as it does not take asymmetrical power relations and repressive aspects of society into consideration. Approaches that stress that everyone today has the opportunity to surveil, that surveillance techniques democratize surveillance societies to a certain degree, and that surveillance has comical, playful, amusing, and even enjoyable characteristics are typical for postmodern scholars and disguise the fact of power and domination in contemporary surveillance societies.

Surveillance studies scholars like Lyon (1994, 119-158; 2001, 40-44) grasp that economic surveillance such as monitoring consumers or the workplace are central aspects of surveillance societies. The following treatment indicates that most of the panoptic notions of surveillance recognize the importance of economic aspects of surveillance: As mentioned at the beginning of this section, Foucault $(1995,141-169)$ analyzes surveillance in the context of the military, medical, educational and industrial institutions. When referring to the industrial institution, Foucault $(1995,145)$ illustrates surveillance in the context of the workplace and concludes: "By walking up and down the central aisle of the workshop, it was possible to carry out a supervision that was both general and individual: to observe the worker's presence and application, and the quality of his work; to compare workers with one another, to classify them according to skill and speed; to follow the successive stages of the production process." Deleuze $(1992,7)$ manifests control in the corporate system as "new ways of handling money, profits, and humans that no longer pass through the old factory form." Zuboff $(1988,324-337)$ studies the panoptic power in two US American corporations namely Cedar Bluff and Metro Tel. She concludes that "techniques of control in the workplace became increasingly important as the body became the central problem of production ... Still struggling to establish their legitimate authority, they invented techniques designed to control the laboring body ... As an informating technology textualizes a wide range of workplace behaviors, new patterns of conduct and sensibility emerge from the heart of the panoptic vision." (Zuboff 1988, 319; 323) 
When Poster describes the emergence of the Superpanopticon in postmodern society, he solely analyzes consumerist aspects of surveillance in the economy: "Indiviudals themselves in many cases fill out the forms; the are at once the source of information and the recorder of the information. Home networking constitutes the streamlined culmination of this phenomenon: the consumer, by ordering products through a modem connected to the producer's database, enters data about himself or herself directly into producer's database in the very act of purchase ... Individuals are constituted as consumers and as participants in the disciplining and surveillance of themselves as consumers." (Poster 1990, 93) Gandy (1993, 80-87) argues on the one hand that the aim of corporations is to get certain behaviours, preferences, usages, interests, and choices of customers in order to identify, classify, and assess certain groups and supply them with targeted advertisements. On the other hand, he stresses that surveillance also takes place in the process of circulation and that surveillance of applications is "required to classify the applicant in terms of eligibility or in relation to the assignment of the applicant to one or more classes of service" (Gandy 1993, 62). Webster and Robins $(1993,95)$ argue that "the subsequent history of capitalist industry ... has been a matter of the deepening and extension of information gathering and surveillance to the combined end of planning and controlling the production process". They also mention that "one fundamental aspect of the 'communications revolution' has been to refine that planning and control of consumer behaviour that was already inherent in the early philosophy of Scientific Management" (Webster and Robins 1993, 100). Elmer $(2003,245)$ states in his panoptic diagram that "consumers are not exclusively disciplined - they are both rewarded, with a preset familiar world of images and commodities, and punished by having to work at finding different and unfamiliar commodities if they attempt to opt-out." Sewell and Wilkinson $(1992,272)$ scrutinize surveillance in the labour process and draw parallels between Foucault's ideas of power, knowledge and surveillance and the phenomenon of post-Fordism: "It is our intention to examine this proposition in greater detail in order that we might be able to draw meaningful parallels between the nature of power, knowledge, and surveillance that Foucault unearthed in his archaeologies and the role of the information superstructure that surrounds the production process in general, and JIT/TQC manufacturing in particular." In conclusion, panoptic theories of surveillance analyze economic aspects of surveillance in different spheres, namely surveillance in the spheres of production, circulation, and consumption. The following table can be outlined:

\begin{tabular}{lll}
\hline Economic Aspects in Panoptic Theories of Surveillance \\
\hline $\begin{array}{l}\text { Surveillance in the Sphere } \\
\text { of Production }\end{array}$ & $\begin{array}{l}\text { Surveillance in the Sphere of } \\
\text { Circulation }\end{array}$ & $\begin{array}{l}\text { Surveillance in the Sphere of } \\
\text { Consumption }\end{array}$ \\
\hline
\end{tabular}

Michel Foucault (1995)

Gilles Deleuze (1992)

Shoshana Zuboff (1988)

Mark Poster (1990)

Oscar Gandy (1993) ～Oscar Gandy (1993)

Frank Webster and Kevin

Robins (1993)

Frank Webster and Kevin Robins (1993)

Greg Elmer (2003)

Graham Sewell and Barry

Wilkinson (1992)

Table 2: Economic aspects in panoptic theories of surveillance 
Although panoptic theories of surveillance recognize the importance of the economy, they tend to focus only on one or two spheres of the economy. Furthermore, panoptic notions of surveillance claim that there are particular forms of economic surveillance without a theoretical criterion for a certain typology. In contrast, a typology of surveillance in the modern economy, which is based on Marx' theory of the political economy, allows to systemize economic surveillance and to distinguish surveillance into the spheres of production, circulation, and consumption. A theoretically founded typology of economic surveillance is important in order to undertake a theoretical analysis of surveillance in the modern economy. Therefore, in the next section, foundations of a political economy approach on surveillance will be outlined.

\section{Critical Surveillance Studies in the Information Society}

A critical contribution to surveillance studies strives for the development of theoretical and empirical research methods in order to focus on surveillance in the context of domination, asymmetrical power relations, resource control, social struggles, and exploitation. It critically analyses surveillance as important aspect for guaranteeing the production of surplus value and for accumulating profit (Fuchs 2008, 268-270). A critical contribution to surveillance studies offers alternative ideas in order to overcome surveillance and to establish political processes and social transformations towards a participatory society (Gandy 1993; Ogura 2006; Andrejevic 2010; Fuchs 2011). According to Lyon (1994, 40-56; also 2001, 107-122), for understanding modern forms of surveillance, the emergence of new technology, primarily information technology, has to be analyzed. Lyon accentuates a remarkable mutation from paper to electronic surveillance, which has caused changes in the economical, political, and cultural system on an intensive and extensive level, and emphasizes four consequences of electronic surveillance: (1) larger and more precise data files are available, (2) monitoring has become more dispersed and nearly every space is surveilled, (3) tempo of dataflows has been increased, and (4) citizens, workers, and consumers are more visible and transparent than before. Lyon $(1994,56)$ concludes that "new ways of understanding surveillance are required in an era of information technology, which take account of the historical development of surveillance systems and also accommodate the new configurations and combinations that constitute the challenge of surveillance today". The Internet can be seen as the most important phenomenon of new information and communication technologies (Fuchs 2008, 139). The overall aim of this section is therefore to analyze the specific economic mode of Internet surveillance. Based on the foundations of a political economy approach, the distinction of production, circulation, and consumption within the economy is introduced (subsection one) in order to establish a typology of Internet surveillance in the economy and to study Internet surveillance in the spheres of production, circulation, and consumption (subsection two).

\subsection{The Spheres of the Economy}

In the Introduction to a Contribution to the Critique of Political Economy, Karl Marx (MECW 28, 2637) distinguishes between (a) production, (b) circulation (distribution and exchange), and (c) consumption as dialectically mediated spheres of the capitalistic economy. (a) The sphere of production appears as the point of departure. In the capitalist mode of production, entrepreneurs purchase means of production and labour power in order to produce commodities and surplus value. (b) Circulation is the "mediation between production and consumption" (MECW 28, 27). In the process of circulation, consumers purchase commodities for daily life and proprietors sell the produced commodities to realize profit. (c) In the sphere of consumption as the final point of the process, "the product drops out of this social movement, becomes the direct object and servant of an individual need, which its use satisfies" (MECW 28, 26). While in the production the person receives an objective aspect, in the consumption the object receives a subjective aspect. The "consumption, as the concluding act, ... reacts on the point of departure thus once again initiating the whole process." (MECW 28, 27) Although production, circulation, and consumption are separated spheres, they correlate in an interconnected relationship (see figure 2): 


\section{Production}

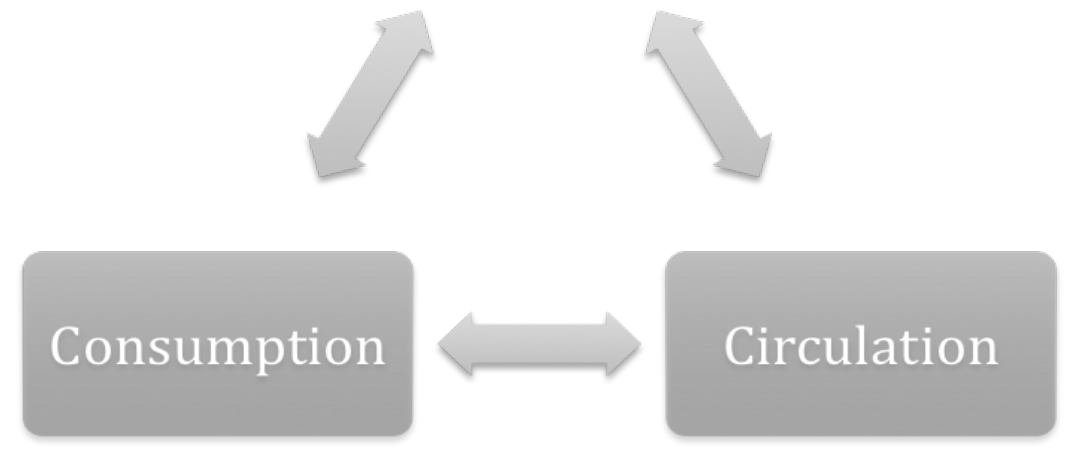

Figure 1: Production, circulation, and consumption as dialectically mediated spheres of the modern economy

In the sphere of production, means of production are consumed and in the sphere of consumption, labour power is (re)produced. "Production is consumption; consumption is production. Consumptive production. Productive consumption." (MECW 28, 30) Production is not possible without demand and consumption does not take place without material. "No consumption without production; no production without consumption." (MECW 28, 30) Moreover, the process of production is determined by circulation of labour power as well as means of production whereas circulation itself is a product of production. Production, circulation, and consumption are not "identical, but that they are all elements of a totality, differences within a unity. ... There is an interaction between the different moments." (MECW 28, 36-37) Nevertheless, production, circulation, and consumption are not equal spheres in the economy; production is rather "the dominant moment, both with regard to itself in the contradictory determination of production and with regard to the other moments. The process always starts afresh with production. ... A definite [mode of; TA] production thus determines a definite [mode of; TA] consumption, distribution, exchange and definite relations of these different moments to one another. Production in its one-sided form, however, is in its turn also determined by the other moments." (MECW 28, 36)

Based on the distinction of production, circulation, and consumption, a typology of surveillance in the economy can be constructed. Such a typology will be outlined in subsection 3.2.

\subsection{Surveillance in the Spheres of the Economy}

This section provides a systematic analysis of economic surveillance on the basis of current developments on the Internet. The vast collection, analysis, and sale of personal data by commercial web platforms such as Google, Facebook, Twitter, YouTube, and Blogger indicate the importance of studying economic surveillance on the Internet. Illustrative examples of economic Internet surveillance in the spheres of production, circulation, and consumption will be presented. The following three sections are therefore structured according to this distinction.

\subsubsection{Surveillance in the Sphere of Production}

Marx analyzes the process of producing capital in Capital, Volume I. The process starts with commodities and money, continues with labour-produced surplus value and methods for producing absolute and relative surplus value, and concludes with the accumulation of capital. For Marx 
(MEW 23, 192-213 ${ }^{1}$ ), production is a unity of the labour process (a) and the process of producing surplus value (b). (a) The labour process is a human activity where, with the help of the instruments of labour, an alteration of material is effected. Marx understands the labour process as a relationship of human activity with its physical and intellectual capabilities on the one hand and the means of production with its instruments and subjects of labour on the other hand. Whereas labour is defined as "a process in which both man and Nature participate, and in which man of his own accord starts, regulates, and controls the material re-actions between himself and Nature." (MEW 23, 192) Furthermore, "the soil ... is the universal subject of human labour" (MEW 23, 193) and an instrument of labour "is a thing, or a complex of things, which the labourer interposes between himself and the subject of his labour, and which serves as the conductor of his activity. He makes use of the mechanical, physical, and chemical properties of some substances in order to make other substances subservient to his aims." (MEW 23, 193) (b) In the capitalist mode of production, entrepreneurs consume purchased labour power as variable capital $(v)$ and purchased means of production as constant capital (c) in order to produce commodities. Constant capital such as raw materials, operating supplies, buildings, equipment etc. does not change its value in the process of production, because the value of constant capital is transferred to the commodity; whereas, labour power as variable capital changes its value during the process of production and produces surplus value (MEW 23, 223). The overall aim of capitalists is to produce as much surplus value as possible in order to accumulate profit. There are two different possibilities for doing so: the production of absolute surplus value by extension of the working day and the production of relative surplus value by intensification of the working day and increasing productivity. "The surplus-value produced by prolongation of the working-day, I call absolute surplus-value. On the other hand, the surplus-value arising from the curtailment of the necessary labour-time, and from the corresponding alteration in the respective lengths of the two components of the working-day, I call relative surplus-value." (MEW 23, 334)

Marx develops the concept of producing relative surplus value as instrument to intensify the working day and introduces co-operation as one possibility for doing so. For Marx, co-operation is an essential part of the capitalist process of production that is defined as a process of many workers collaborating with each other in one process or many related processes of production in order to work systematically side by side and together (MEW 23, 344). He highlights the importance and necessity of control, supervision, and surveillance in order to guarantee co-operation, the production of relative surplus value, and therefore achieve accumulation of capital: "The work of directing, superintending, and adjusting, becomes one of the functions of capital, from the moment that the labour under the control of capital, becomes co-operative ... In proportion to the increasing mass of the means of production, now no longer the property of the labourer, but of the capitalist, the necessity increases for some effective control over the proper application of those means ... Just as at first the capitalist is relieved from actual labour so soon as his capital has reached that minimum amount with which capitalist production, as such, begins, so now, he hands over the work of direct and constant supervision of the individual workmen, and groups of workmen, to a special kind of wage-labourer. An industrial army of workmen, under the command of a capitalist, requires, like a real army, officers (managers), and sergeants (foremen, overlookers), who, while the work is being done, command in the name of the capitalist. The work of supervision becomes their established and exclusive function." (MEW 23, 350-351)

The Electronic Monitoring and Surveillance Survey (American Management Association and the ePolicy Institute 2008) offers interesting examples of surveillance in the sphere of production: According to the American Management Association and the ePolicy Institute (2008) that undertake an annual quantitative survey about electronic monitoring and surveillance with approximately 300 US companies, "more than one fourth of employers have fired workers for misusing e-mail and nearly one third have fired employees for misusing the Internet". More than $40 \%$ of the studied companies monitor e-mail traffic of their workers, and $66 \%$ of the corporations monitor Internet connections. In addition, most companies use software to block non-work related websites such as

\footnotetext{
${ }^{1}$ All translations from: http://www.marxists.org/archive/marx/works/cw/volume35/index.htm (September 17, 2011)
} 
sexual or pornographic sites, game sites, social networking sites, entertainment sites, shopping sites, and sport sites. The American Management Association and the ePolicy Institute (2008) also stress that companies track "content, keystrokes, and time spent at the keyboard ... store and review computer files ... monitor the blogosphere to see what is being written about the company, and ... monitor social networking sites". Furthermore, about $30 \%$ of the companies had also fired employees for non-work related email and Internet usage such as "inappropriate or offensive language" and "viewing, downloading, or uploading inappropriate/offensive content" (American Management Association and the ePolicy Institute 2008). This example shows that companies use surveillance and exercise violence in order to control certain behaviour of workers. Corporations control the economic behaviour of people and coerce individuals in order to produce specific commodities for accumulating profit and for guaranteeing the production of surplus value. In the modern production process, primarily electronic surveillance is used to document and control workers' behaviour and communication for guaranteeing the production of surplus value.

\subsubsection{Surveillance in the Sphere of Circulation}

For understanding the sphere of circulation of the capitalistic economy and surveillance in it, it is helpful to analyze how Marx described the circuit of capital in Capital, Volume II. For Marx, the circuit of capital contains three stages, namely the stage of money capital (sphere of circulation), the stage of productive capital (sphere of production), and the stage of commodity capital (sphere of circulation).

The first stage of the circuit of capital starts with a certain amount of money (M), which at this stage is money capital. With this money, the capitalist purchases two different commodities (C), namely labour power $(\mathrm{L})$ and means of production $(\mathrm{mp})$. This act can be expressed as follows:

$$
M-C\left\{_{m p}^{L}\right.
$$

Money is transformed into commodities and the capitalist appears as a buyer. It is a transformation of money capital to commodity capital. With labour power and means of production, the capitalist is able to start the process of production. (Marx 1992, 110-118)

The second stage of the circuit of capital is a productive process. The capitalist consumes the purchased commodities in order to produce a new commodity ( $\left.C^{\prime}\right)$ with an increased value because of surplus labour. $\mathrm{P}$ indicates the process of production. The dots signify that the sphere of circulation is interrupted by the sphere of production. This act can be expressed as follows:

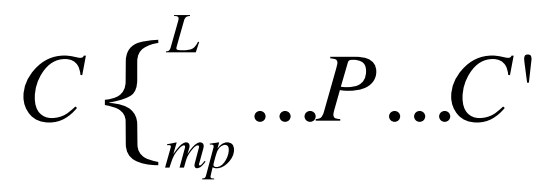

With a commodity of greater value than its single elements of production, the capitalist is able to sell the commodity on the market. (Marx 1992, 118-121)

In the third stage of the circuit of capital, the capitalist sells the commodity on the market and transforms the commodity into money. The capitalist finishes with a greater amount of money (M') than what he owned at the beginning. This act can be expressed as follows:

$$
C^{\prime}-M^{\prime}
$$


The capitalist turns back to the market as a seller. It is a transformation of commodity capital to money capital. (Marx 1992, 121-131)

"We have seen how the circulation process, after its first phase ... has elapsed, is interrupted by $P$, in which the commodities bought on the market, $L$ and $m p$, are consumed as material and value components of the productive capital; the product of this consumption is a new commodity, M', altered both materially and in value. The interrupted circulation process, $\mathrm{M}-\mathrm{C}$, must be supplemented by C-M." (Marx 1992, 131f.) Finally, the circuit as a whole can be expressed as follows:

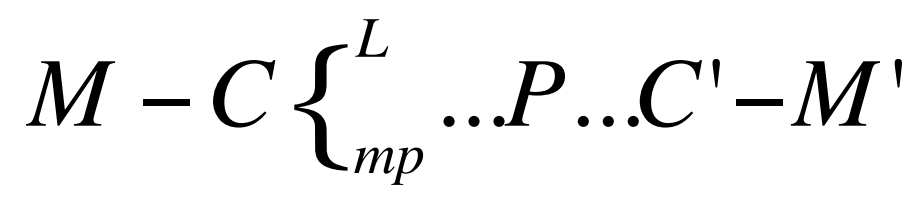

The first and the last stage take place in the sphere of circulation, whereas the second stage takes place in the sphere of production. Only in the sphere of production surplus value is produced. The sphere of circulation represents a transformation of money capital to commodity capital and a transformation of commodity capital to money capital. (Marx 1992, 131-143) "Here capital appears as a value that passes through a sequence of connected and mutually determined transformations, a series of metamorphoses that form so many phases or stages of a total process. Two of these phases belong to the circulation sphere, one to the sphere of production. In each of these phases the capital value is to be found in a different form, corresponding to a different and special function. Within this movement the value advanced not only maintains itself, but it grows, increases its magnitude. Finally, in the concluding stage, it returns to the same form in which it appeared at the outset of the total process. This total process is therefore a circuit." (Marx 1992, 132f.)

By knowing the sphere of circulation in the circuit of capital, one is able to identify surveillance in the sphere of circulation:

\section{A. Surveillance of Purchasing Labour Power in the Stage of Money Capital}

Surveillance of purchasing labour power in the stage of money capital means applicant surveillance. Applicant surveillance is useful for getting the most suitable labour power, which is able to produce the most surplus value and with means of production creates a new commodity of the greatest possible value in order to sell the commodity and to accumulate as much profit as possible. Lyon $(2001,41)$ stresses in this context that "before an employee is even hired, she or he is likely to be checked, using special databases (including data mining techniques) or genetic screening, to discover the likelihood of this or that person turning out to be a responsible and hardworking employee." Gandy $(1993,62)$ argues that the corporate file "begins with the application" and that "applications are required to classify the applicant in terms of eligibility or in relation to the assignment of the applicant to one or more classes of service".

Surveillance of purchasing labour power in the stage of money capital means online applicant surveillance: Rosalind Searle $(2006,343)$ states in this context that "checking procedures are increasingly utilised to authenticate candidates' data. In several countries financial services authorities have sanctioned formal vetting, often outsourcing it to external contractors. The growth in the collection and sale of information databases can be seen by the proliferation of information verification firms, such as Kroll and Carratu International." The New York-based risk consulting company Kroll undertakes off- and online pre-employment screening on a large-scale level. Kroll is an operating unit of the insurance and professional services firm Marsh \& McLennan, which is the 832nd biggest company worldwide (Forbes 2009). Kroll's revenues of 2008 were US\$ 866 million (Kroll 2010). Kroll offers background screening services of new job applicants for companies and government agencies in order to check information such as address histories, education and employment histories, media coverage, credit reports, civil and bankruptcy records, criminal records, 
driving histories, liens and judgment histories, and professional licenses and certifications (Kroll 2010). If Kroll realizes a company's application procedure, the job candidates have to fill out a detailed questionnaire on the Internet as part of their application, which is sent invisibly to Kroll (Searle 2006, 343). "Kroll has pioneered a secure Internet-based system that collects information from job candidates and provides clients with project updates and final reports. Kroll's Applicant Submission System allows job candidates to fill out a detailed questionnaire online and submit it securely to Kroll." (Kroll 2010) In order to investigate job candidates, Kroll "searches primary sources (including electronic resources), visits courthouses throughout the country to retrieve and review public documents, and conducts telephone interviews with a job candidate's professional and personal references" (Kroll 2010). Kroll is a threat to the job candidates' privacy, because the applicants assume their personal information is only shared with the company, where they are applying, but the candidates do not know that their information is sent to Kroll. Kroll and their entrepreneurial clients use surveillance and exercise violence in order to control certain behaviour of people. Kroll also offers surveillance services of existing employees such as monitoring e-mail traffic and Internet usage (Internet surveillance in the sphere of production). This indicates that economic surveillance also occurs in combinations of different spheres and that forms of surveillance in the sphere of production, circulation, and consumption are interconnected.

\section{B. Surveillance of Purchasing Means of Production in the Stage of Money Capital}

Surveillance of purchasing means of production in the stage of money capital includes screening of suppliers: Kroll (2010) provides a so-called off- and online commercial intelligence program in order to check existing and potential suppliers. According to Kroll (2010), the service "goes beyond the published data" and gives your company "a real sense of who you are doing business with". Kroll (2010) screens primary source data and analysis of suppliers, performance benchmarking in the sector of suppliers, and collects information based on industry knowledge and contacts. As claimed by Kroll (2010), the "advantage lies in being able to give you the right information, at the right time, to help you make the best possible decision ... By accessing reliable and effective commercial intelligence from Kroll, you will gain the confidence to make sound business decisions that will enhance your corporate reputation and bottom line performance".

\section{Surveillance of Produced Commodities in the Stage of Commodity Capital}

Surveillance of produced commodities in the stage of commodity capital contains (material and immaterial) property surveillance as well as surveillance of vendors: Carratu International offers socalled Intellectual Property Protection Services (IPPS) off- and online on behalf of brand, trademark, and patent owners. It includes services such as anti-counterfeiting investigations, trademark infringement and passing-off investigations, market watch, patent investigations, and parallel trade investigations. In order to avoid product counterfeiting, Carratu International provides "brand owners and their legal representatives a unique range of anti-counterfeiting programmes, tracking infringements from point of sale to source, identifying those responsible and building up a comprehensive supply chain diagnosis. We obtain the evidence needed to bring an enforcement action and support clients through the entire process." Furthermore, the corporate investigation company undertakes trademark infringement and passing-off investigations: "Whether it is your company name or one of your registered or un-registered trademarks, we investigate those individuals behind the infringement and provide you with sufficient evidence to take the appropriate action." (Carratu International) The company also offers a market watch service. This service "constantly monitors all likely distribution centres with each area covered by a watcher, or watchers, who submit monthly intelligence reports on the outlets and venues checked. If an infringement is found, a test purchase is completed and, when requested, we liaise with the local authorities to ensure that wherever possible, enforcement action is taken." (Carratu International) In addition, Carratu International carries out parallel trade investigations and assists "trademark owners in determining who is behind the supply of parallel goods and to secure the necessary evidence to take enforcement action and so safeguard regional markets and profits." 
Kroll (2010) provides a so-called off- and online vendor integrity program in order to check existing and potential vendors whether they "have criminal records, financial troubles, or business relationships that could create costly conflicts or be deeply embarrassing" or "could have a negative impact on your company's revenues and reputation". Therefore, Kroll (2010) screens criminal records, bankruptcy records, illegal activity allegations, civil cases, liens, as well as media coverage of vendors. For doing so, vendors have to "complete a detailed online questionnaire that's electronically submitted to Kroll ..., Kroll's staff screens the information provided by vendors and collect additional intelligence" (Kroll 2010) and publishes an online report.

In conclusion, the circuit of capital contains three stages, namely the stage of money capital, the stage of productive capital, and the stage of commodity capital. Based on these findings, surveillance in the sphere of circulation consists of applicant surveillance, screening of suppliers, property surveillance, and surveillance of vendors. The next point of discussion is the sphere of consumption.

\subsubsection{Surveillance in the Sphere of Consumption}

Marx (MECW 28, 30) notes that "production produces consumption: (1) by creating the material for consumption; (2) by determining the mode of consumption; (3) by creating in the consumer a need for the products which it first posits as objects" and concludes that production "produces the object of consumption, the mode of consumption and the urge to consume." Nevertheless, in order to know which mode of production generates which mode of consumption of different consumers, knowledge of consumption matters is required. Although the emergence of mass consumption in modern societies promises individuality, free choice, sovereignty, and freedom of consumers, it synchronously requires knowledge of consuming activities in order to stimulate and steer consumption (Lyon 1994, 137). Advertising as a product of modern society is an important instrument for realizing profit, because it induces people to consume more products or services through branding. The more data are available, the more precise and effective are the targeted advertisements. Consumer surveillance can be seen as a product of the capitalistic economy (Lyon 1994, 138; Gill 2003, 25ff.; Ogura 2006, 293f.; Brown 2006, 18ff.; see also Hewson 1994). In order to target advertising, market research such as analyzing behaviour, preferences, and interests of consumers is important. The basic question for market research is who buys where, when, what and why. The overall aim is to get certain behaviours, preferences, usages, interests, and choices of customers in order to identify, classify, and assess (Gandy 1993, 80-87) certain groups and supply them with targeted advertisements. As Theodor W. Adorno and Max Horkheimer (2002, 96f.) put it: "Sharp distinctions like those between A and B films, or between short stories published in magazines in different price segments, do not so much reflect real differences as assist in the classification, organization, and identification of consumers." So, "for the consumer there is nothing left to classify, since the classification has already be preempted by the schematism of production." (Adorno and Horkheimer 2002, 98) Corporations are interested in collecting and generating as much data as possible (qualitative level) from as many people as possible (quantitative level).

For surveillance in the sphere of consumption, the example of Google and DoubleClick can be outlined: According to the top sites of the web by Alexa Internet, Google has the most visits on the Internet. Google uses a wide range of methods in order to collect data on its users, namely click tracking (to log clicks of users), log files (to store server requests), JavaScript and web bugs (to check users visits), as well as cookies (to record individual actions) (Stalder and Mayer 2009, 102). DoubleClick is one of the main projects of Google (Google 2008). It is a global leader in ad serving and has developed sophisticated methods in order to collect, analyze, and assess huge amounts of users' data on the Internet (Campbell and Carlson 2002, 596-597). Google (2007; 2008) acquired DoubleClick in 2008 for US\$ 3.1 billion. DoubleClick is headquartered in New York City. It was found in 1996 and works for leading digital publishers, marketers, and agencies around the world such as About, Durex, Ford, Friendster, Optimedia, Scripps, and MTV (DoubleClick). Ad serving companies such as DoubleClick use methods by placing advertisements on websites and analyzing their efficiency. DoubleClick develops and provides Internet ad serving services that are sold 
primarily to advertisers and publishers. DoubleClick collects personal data on many websites, sells this data, and supports targeted advertising. DoubleClick's main product is known as DART (Dynamic Advertising, Reporting, and Targeting). DART is an ad serving programme working with a complex algorithm and is primarily developed for publishers and advertisers in order to "ensure you get the right message, to the right person, at the right time, on the right device" (DoubleClick). DoubleClick collects personal data such as individual behaviour, preferences, and interests on many websites with the help of systematic and automated computer processes and sells these data to advertising agencies in order to guarantee the production of surplus value and to accumulate profit.

In this section, surveillance in the context of the economy was analyzed. Based on the foundations of a critical political economy approach, the distinction of production, circulation, and consumption in the economy was introduced in order to establish a typology of surveillance in the economy. This section provided a systematic treatment of economic surveillance on the basis of current developments on the Internet.

\section{Conclusion}

The overall aim of Critical Surveillance Studies in the Information Society was to clarify how we can theorize and systemize surveillance in the modern economy. This paper constructed theoretically founded typologies in order to systemize the existing literature of surveillance studies and to analyze examples of surveillance. Therefore, it mainly was a theoretical approach combined with illustrative examples, advanced from the abstract to the concrete level.

Foundations of surveillance studies were discussed in the second section. In the third section, a critical contribution to surveillance studies was drawn in order to distinguish surveillance into the spheres of production, circulation, and consumption. Based on these findings, we were able to systemize economic surveillance on the basis of current developments on the Internet such as the Electronic Monitoring and Surveillance Survey, Kroll, Carratu International, and DoubleClick into the spheres of production, circulation, and consumption.

As shown in this contribution, economical actors such as corporations undertake surveillance and exercise violence in order to control a certain behaviour of people and in most cases people do not know that they are surveilled. Corporations control the economic behaviour of people and coerce individuals in order to produce or buy specific commodities for guaranteeing the production of surplus value and for accumulating profit. As the examples in section three have shown, this is particularly evident regarding the Internet. For example, the Internet enables the vast collection, analysis, and sale of personal data by commercial web platforms such as Google. Therefore, one can assume that surveillance in general and Internet surveillance in particular are negative phenomena of modern societies, which should be questioned and struggled against. Based on Gandy (1993, 230-231), Castells (2001, 182-184), Parenti (2003, 207-212), Ogura (2006, 291-293), Lyon (1994, 159-225; 2001, 126-140; 2007a, 159-178; 2007b, 368-377), Fuchs (2009, 115-117), and Allmer $(2011,142)$ some political recommendations can be drawn in order to overcome economic surveillance:

- The first recommendation is that support is needed for critical privacy movements in order to develop counter-hegemonic power and advance critical awareness of surveillance.

- "Such public awareness of surveillance issues could further be raised through professional groups and organizations, especially those directly concerned with computing, information management, and so on." (Lyon 1994, 223)

- Furthermore, Lyon $(2001,127)$ states the importance of political activism by critical citizens: "Films, consumer groups, Internet campaigns and international watchdogs are just some of the ways that ongoing surveillance practices are brought to the surface of our consciousness, and thus overtly into the realm of ethical evaluation and political response." 
- According to Fuchs $(2009,116)$, "critical citizens, critical citizens' initiatives, consumer groups, social movement groups, critical scholars, unions, data protection specialists/groups, consumer protection specialists/groups, critical politicians, critical political parties observe closely the relationship of surveillance and corporations and document instances where corporations and politicians take measures that threaten privacy or increase the surveillance of citizens".

- In addition, it is recommended to support cyberactivism and "counter-surveillance" (Lyon 1994, $159)$ in order to surveil corporate surveillants or rather to watch the watchers.

- Parenti $(2003,212)$ suggests civil disobedience, rebellion, and protest: "It will compel regulators to tell corporations, police, schools, hospitals, and other institutions that there are limits. As a society, we want to say: Here you may not go. Here you may not record. Here you may not track and identify people. Here you may not trade and analyze information and build dossiers".

- A further recommendation is to create non-profit, non-commercial social networking platforms on the Internet such as Kaioo (Fuchs 2009, 116). Kaioo is owned by the non-profit organization OpenNetworX, has been available since 2007, and has currently about 30.000 users. Kaioo's privacy terms are created in common and can be edited online by every user. In addition, the data belong to their users (Kaioo). OpenNetworX can do so, because they are not interested in targeting advertising and they do not need to produce surplus value and to accumulate profit.

- "To try to advance critical awareness and to surveil corporate and political surveillers are important political moves for guaranteeing civil rights, but they will ultimately fail if they do not recognize that electronic surveillance is not a technological issue that can be solved by technological means or by different individual behaviours, but only by bringing about changes of society" (Fuchs 2009, 116). Therefore, surveillance has to be put into the larger context of societal problems in public discourse. "We should look at the whole macro picture." (Ogura 2006, 292)

- Finally, surveillance is caused by economical and political issues and is inherent in modern society. It is neither just a technical issue, nor an individual problem, but a societal problem. Surveillance is a crucial phenomena, but there are a lot of other features in contemporary society such as information, neoliberalism, globalization, and capital.

\section{References}

Adorno W., T. \& Horkheimer, M. (2002). Dialectic of Enlightenment: Philosophical Fragments. Stanford: Stanford University Press.

Albrechtslund, A. (2008). Online Social Networking as Participatory Surveillance. First Monday, 13(3). Retrieved September 26, 2011 from http://firstmonday.org/htbin/cgiwrap/bin/ojs/index.php/fm/article/view/2142/1949

Albrechtslund, A. \& Dubbeld, L. (2005). The Plays and Arts of Surveillance: Studying Surveillance as Entertainment. Surveillance \& Society 3(2/3): 216-221.

Alexa, Internet. Retrieved September 26, 2011 from http://www.alexa.com

Allmer, T. (2011). Critical Internet Surveillance Studies and Economic Surveillance. In C. Fuchs, K. Boersma, A. Albrechtslund \& M. Sandoval (Ed.), Internet and Surveillance: The Challenge of Web 2.0 and Social Media (pp. 124143). New York: Routledge.

American Management Association \& The ePolicy Institute (2008). Electronic Monitoring and Surveillance 2007 Survey. Retrieved September 26, 2011 from http://www.amanet.org/training/seminars/2007-Electronic-Monitoring-andSurveillance-Survey-41.aspx

Andrejevic, M. (2010). Social Network Exploitation. In Z. Papacharissi (Ed.), A Networked Self: Identity, Community, and Culture on Social Network Sites (pp. 82-101). New York: Routledge.

Baudrillard, J. (2006). Simulacra and Simulation. Michigan: University of Michigan.

Baudrillard, J. (2007). Forget Foucault. Los Angeles: Semiotext(e).

Beniger, J. (1986). The Control Revolution. Technological and Economic Origins of the Information Society. Cambridge: Harvard University Press.

Bigo, D. (2006). Security, Exception, Ban and Surveillance. In D. Lyon (Ed.), Theorizing Surveillance: The Panopticon and Beyond (46-68). Cullompton: Willan Publishing.

Bigo, D. (2008). Globalized (In)Security: The Field and the Ban-Opticon. In D. Bigo \& A. Tsoukala (Ed.), Terror, Insecurity and Liberty: Illiberal Practices of Liberal Regimes after 9/11 (10-48). London: Routledge. 
Blanchette, J.-F. \& Johnson, D. (2002). Data Retention and the Panoptic Society: The Social Benefits of Forgetfulness. The Information Society 18(1): 33-45.

Bogard, W. (1996). The Simulation of Surveillance: Hypercontrol in Telematic Societies. Cambridge: Cambridge University Press.

Bogard, W. (2006). Surveillance Assemblages and Lines of Flight. In D. Lyon (Ed.), Theorizing Surveillance: The Panopticon and Beyond (97-122). Cullompton: Willan Publishing.

Boyne, R. (2000). Post-Panopticism. Economy and Society 29(2): 285-307.

Brown, F. (2006). Rethinking the Role of Surveillance Studies in the Critical Political Economy of Communication. International Association for Media and Communication Research (IAMCR) Prize in Memory of Dallas W. Smythe, Cairo, 2006. Retrieved September 26, 2011 from https://www.iamcr.org/component/option,com_docman/task,doc_download/gid,32

Campbell, J. E. \& Carlson, M. (2002). Panopticon.com: Online Surveillance and the Commodification of Privacy. Journal of Broadcasting \& Electronic Media 46 4): 586-606.

Carratu International. Retrieved September 26, 2011 from http://www.carratu.com

Castells, M. (2001). The Internet Galaxy: Reflections on the Internet, Business, and Society. Oxford: Oxford University Press.

Clarke, R. (1988). Information Technology and Dataveillance. Communications of the ACM 31(5): 498-512.

Cohen, S. (1987). Visions of Social Control: Crime, Punishment and Classification. Cambridge: Polity Press.

Coleman, R. \& Sim, J. (2000). 'You'll Never Walk Alone': CCTV Surveillance, Order and Neo-Liberal Rule in Liverpool City Centre. The British Journal of Sociology 51(4): 623-639.

Dandeker, C. (1990). Surveillance, Power, and Modernity: Bureaucracy and Discipline from 1700 to the Present Day. New York: St. Martin's Press.

Deleuze, G. (1988). Foucault. Minneapolis: University of Minnesota Press, 2006.

Deleuze, G. (1992). Postscript on the Societies of Control. October (59): 3-7.

DoubleClick. Retrieved September 26, 2011 from http://www.doubleclick.com.

Elden, S. (2003). Plague, Panopticon, Police. Surveillance \& Society 1(3): 240-253.

Elmer, G. (2003). A Diagram of Panoptic Surveillance. New Media Society 5(2): 231-247.

Elmer, G. (2004). Profiling Machines: Mapping the Personal Information Economy. Massachusetts: MIT Press.

Fiske, J. (1998). Surveilling the City: Whiteness, the Black Man and Democratic Totalitarianism. Theory Culture Society 15(2): 67-88.

Fiske, J. (1999). Media Matters: Race and Gender in U.S. Politics. Minneapolis: University of Minnesota Press.

Forbes. (2009). The Global 2000. Retrieved September 26, 2011 from http://www.forbes.com/lists/2009/18/global-09 TheGlobal-2000_Rank.html.

Foucault, M. (1995). Discipline and Punish: The Birth of the Prison. New York: Vintage Books.

Foucault, M. (2002). The Eye of Power: A Conversation with Jean-Pierre Barou and Michelle Perrot. In T. Levin, U. Frohne, \& P. Weibel (Ed.), CTRL [Space] Rhetorics of Surveillance from Bentham to Big Brother (pp. 94-101). Karlsruhe: ZKM Center for Arts and Media.

Foucault, M. (2003). Society Must Be Defended: Lectures at the Collège De France, 1975-76. New York: Picador.

Foucault, M. (2007). Security, Territory, Population: Lectures at the Collège De France, 1977-1978. New York: Palgrave Macmillan.

Fuchs, C. (2008). Internet and Society: Social Theory in the Information Age. New York: Routledge.

Fuchs, C. (2009). Social Networking Sites and the Surveillance Society: A Critical Case Study of the Usage of studiVZ, Facebook, and MySpace by Students in Salzburg in the Context of Electronic Surveillance. Salzburg: Research Group Unified Theory of Information.

Fuchs, C. (2011). Critique of the Political Economy of Web 2.0 Surveillance. In C. Fuchs, K. Boersma, A. Albrechtslund \& M. Sandoval (Ed.), Internet and Surveillance: The Challenge of Web 2.0 and Social Media (in press). New York: Routledge.

Gandy, O. (1993). The Panoptic Sort: A Political Economy of Personal Information. Boulder: Westview Press.

Gandy, O. (2003). Data Mining and Surveillance in the Post-9/11 Environment. In K. Ball \& F. Webster (Ed.), The Intensification of Surveillance. Crime, Terrorism and Warfare in the Information Era (pp. 26-41). London: Pluto Press.

Giddens, A. (1985). The Nation-State and Violence: Volume Two of a Contemporary Critique of Historical Materialism. Cambridge: Polity Press.

Giddens, A. (1995). A Contemporary Critique of Historical Materialism. Stanford: Stanford University Press.

Gill, S. (2003). "Übermacht und Überwachungsmacht im globalen Kapitalismus.” Das Argument (249): 21-33.

Google. (2007). Press Center: Google to Acquire DoubleClick: Combination Will Significantly Expand Opportunities for Advertisers, Agencies and Publishers and Improve Users' Online Experience. Retrieved September 26, 2011 from http://www.google.com/intl/en/press/pressrel/doubleclick.html 
Google. (2008). Press Center: Google Closes Acquisition of DoubleClick. Retrieved September 26, 2011 from http://www.google.com/intl/en/press/pressrel/20080311 doubleclick.html

Google. (2010). Scholar Search: Discipline and Punish. Retrieved September 26, 2011 from http://scholar.google.com

Gutting, G. (1998). Foucault, Michel (1926-84). In E. Craig (Ed.), Routledge Encyclopedia of Philosophy. Volume 4 (pp. 708713). London: Routledge.

Haggerty, K. \& Ericson, R. (2000). The Surveillant Assemblage. British Journal of Sociology 51(4): 605-622.

Hewson, M. (1994). Surveillance and the Global Political Economy. In E. Comor (Ed.), The Global Political Economy of Communication: Hegemony, Telecommunication and the Information Economy. Basingstoke: Macmillan.

Hier, S. (2003). Probing the Surveillant Assemblage: On the Dialectics of Surveillance Practices as Processes of Social Control. Surveillance \& Society 1(3): 399-411.

Hier, S. (2004). Risky Spaces and Dangerous Faces: Urban Surveillance, Social Disorder and CCTV. Social \& Legal Studies 13(4): 541-554.

Kaioo. About Kaioo. Retrieved September 26, 2011 from http://kaioo.com/toro/resource/html?locale=en\#wiki.9.

Koskela, H. (2004). Webcams, TV Shows and Mobile Phones: Empowering Exhibitionism. Surveillance \& Society 2(2/3): 199-215.

Koskela, H. (2006). 'The Other Side of Surveillance': Webcams, Power and Agency. In D. Lyon (Ed.), Theorizing Surveillance: The Panopticon and Beyond (pp. 163-181). Cullompton: Willian Publishing.

Kroll. (2010). Retrieved September 26, 2011 from http://www.kroll.com/

Lianos, M. (2003). Social Control after Foucault. Surveillance \& Society 1(3): 412-430.

Lyon, D. (1994). The Electronic Eye: The Rise of Surveillance Society. Minneapolis: University of Minnesota Press.

Lyon, D. (2001). Surveillance Society: Monitoring Everyday Life: Issues in Society Maidenhead: Open University Press.

Lyon, D. (2003). Surveillance after September 11. Cambridge: Polity Press.

Lyon, D. (2007a). Surveillance Studies: An Overview. Cambridge: Polity.

Lyon, D. (2007b). Resisting Surveillance. In S. Hier \& J. Greenberg (Ed.), The Surveillance Studies Reader (pp. 368-377). Maidenhead: Open University Press.

Mann, S., Jason, N. \& Wellman, B. (2003). Sousveillance: Inventing and Using Wearable Computing Devices for Data Collection in Surveillance Environments. Surveillance \& Society 1(3): 331-355.

Marx, G. (1988). Undercover: Police Surveillance in America. Berkeley: University of California Press.

Marx, G. (2002). What's New About the "New Surveillance"? Classifying for Change and Continuity. Surveillance \& Society 1(1): 8-29.

Marx, K. (1992). Capital: A Critique of Political Economy: Volume Two. London: Penguin.

Marx, K. (MEW 23). (2005). Das Kapital: Kritik der politischen Ökonomie: Erster Band: Der Produktionsprozeß des Kapitals. Berlin: Dietz.

Marx, K. \& Engels, F. (MECW 28). (1986). Collected Works: Volume 28. New York: International Publishers.

Mathiesen, T. (1997). The Viewer Society: Michel Foucault's 'Panopticon' Revisited. Theoretical Criminology 1(2): $215-234$.

Murakami Wood, D. (2003). Editorial. Foucault and Panopticism Revisited. Surveillance \& Society 1(3): 234-239.

Norris, C. \& Armstrong, G. (1998). Introduction: Power and Vision. In C. Norris, J. Moran \& G. Armstrong (Ed.), Surveillance, Closed Circuit Television and Social Control (pp. 3-18). Aldershot: Ashgate Publishing.

Norris, C. \& Armstrong, G. (1999). The Maximum Surveillance Society: The Rise of CCTV. Oxford: Berg.

Ogura, T. (2006). Electronic Government and Surveillance-Oriented Society. In D. Lyon (Ed.), Theorizing Surveillance: The Panopticon and Beyond (pp. 270-295). Cullompton: Willan Publishing.

Orwell, G. (2004). Nineteen Eighty-Four. Fairfield: 1st World Library.

Parenti, C. (2003). The Soft Cage: Surveillance in America: From Slavery to the War on Terror. New York: Basic Books.

Poster, M. (1990). The Mode of Information: Poststructuralism and Social Context. Cambridge: Polity Press.

Pryor, B. (2006). Foucault, Michel (1926-1984). In D. Borchert (Ed.), Encyclopedia of Philosophy. Volume 3 (pp. 698-702). Detroit: Thomson Gale.

Rule, J. (1973). Private Lives and Public Surveillance: Social Control in the Computer Age. New York: Schocken Books.

Rule, J. (2007). Privacy in Peril. How We Are Sacrificing a Fundamental Right in Exchange for Security and Convenience. Oxford: Oxford University Press.

Searle, R. (2006). New Technology: The Potential Impact of Surveillance Techniques in Recruitment Practices. Personal Review 35(3): 336-351.

Sewell, G. \& Wilkinson, B. (1992). 'Someone to Watch over Me': Surveillance, Discipline and the Just-in-Time Labour Process. Sociology 26(2): 271-289.

Simon, B. (2005). The Return of Panopticism: Supervision, Subjection and the New Surveillance. Surveillance \& Society $3(1): 1-20$.

Stalder, F. \& Mayer, C. (2009). The Second Index: Search Engines, Personalization and Surveillance. In K. Becker \& F. Stalder (Ed.), Deep Search: The Politics of Search Beyond Google (pp. 98-116). Wien: Studienverlag. 
Vaz, P. \& Bruno, F. (2003). Types of Self-Surveillance: From Abnormality to Individuals 'at Risk'. Surveillance \& Society 1(3): 272-291.

Webster, F. \& Robins, K. (1993). 'I'll Be Watching You': Comment on Sewell and Wilkinson. Sociology 27(2): 243-252.

Williams, K. \& Johnstone, C. (2000). The Politics of the Selective Gaze: Closed Circuit Television and the Policing of Public Space. Crime, Law and Social Change 34(2): 183-210.

Zuboff, S. (1988). In the Age of the Smart Machine: The Future of Work and Power. Oxford: Heinemann Professional Publishing.

Zureik, E. (2003). Theorizing Surveillance: The Case of the Workplace. In D. Lyon (Ed.), Surveillance as Social Sorting: Privacy, Risk, and Digital Discrimination (pp. 31-56). London: Routledge.

\section{About the Author}

\section{Thomas Allmer}

has studied Media and Communication at the University of Salzburg and the Victoria University of Melbourne. Currently, he is a PhD candidate at the University of Salzburg and Research Associate in the project "Social Networking Sites in the Surveillance Society", funded by the Austrian Science Fund (FWF). He is a member of the Unified Theory of Information Research Group (UTI) and participates in the working group "Living in the Surveillance Age" of the European Cooperation in Science and Technology Action "Living in Surveillance Societies". 